\title{
DEATH IN 2020 AND A COVID-19 GREAT EPIDEMIC: AN ISLAMIC ANALYSIS
}

\author{
Md. Kohinoor Hossain \\ Dept. of Islamic History \& Culture, Dargahpur Fazil Degree Madrasha \\ Gournagar, Bagherpara, Jashore, Bangladesh \\ ap.m.k.hossain@gmail.com
}

\begin{abstract}
Love to Allah is the greatest love from ages to ages, sending His messengers to preach love to Him. Many destruction, disruptions and explosion have been occurred in this world. This paper tries to explore about the causes the great disasters in the world by he global people leading an invalid way and creating a terrible crisis. Allah can save the global people. The present world is full of share-ism, idolatry-ism, usury-ism, Zakat-free-ism, killing-ism, injustice-ism, inhumanity-ism, practice about Gods and Goddesses, believe the sun, the moon, the stars, the trees, the stone, the angels, the jinn, other animals, practice as same-sex, polygamy, polygyny, polyandry, pray to materials, death guru, peer, saai, baba, abba, dihi baba, langta baba, khaja baba, joy guru, joy chisty, joy baba hydery, joy maa kali, maa durga, moorshid kibla, baba haque bhandary, joy ganesh pagla, joy deawan baggi, joy chandrapa, joy sureshwaree, fooltali kebla, sharshina kebla, foorfoora kebla, joy ganapati, joy krishnan, joy hari, joy bhagaban and Mazzarians, Marriages and sexism into human to animal, reaching to Allah. Manmade religions have created as Baha'i, Kadyany, Khaljee, Din-E-Elahi, Brahma and Humanism. The world is full of Shirkism, Moonafikism, Goboatism, Bohtanism, Mooshrikiaism, Oathlessism and Khianotkariism. This Covid-19 is caused above them. Covid-19 is humanmade. It will be explored by the teaching of the Qur'an.
\end{abstract}

Keywords: Scientific Inventions, Social Unrest, Marriage and Sex, Religion and Belief, Weep of Womankind, Economical Unrest, Killing Method

Submission Date Accepted Date

Review Date Publish Date
June 11,2020

June 13, 2020

; November 08, 2020

: December 20, 2020 



\section{INTRODUCTION}

When was this world created? None can answer origination. When was human being exist? None can answer accurately. From the eternal time, this world is ruled by human. There are huge numbers of civilizations which have been decayed but time is old gypsy man. All makers of these civilizations have damaged and died. None can return into the earth. It is the main rules of Allah. Allah creates them. Allah gives their death.

The global people have forgotten Allah. They have made their own thinktank. They invent newest things but they pray to human-made Gods and Goddesses which are soil-made or stonemade or iron-made or steel-made idolatry, trees, stones, sun, moon, star, animal, fire, jinn, angels, man and woman. They are sharing to the Super power Allah. They are making state by their own composed think-tank. They have made state sculptor like idolatry. They worship to Peer, Saai, Baba, Khaja Baba, Joy Guru, Dihi Baba, ChistyBaba, Clergy, pope, Benedict, Parson, Maa kali, MaaDurga, Mother Mary, Father, Son, Hare Krishnan, Hare Ram, Shivam, Bishnu, Baha'i, Kadiany, Din -E-Elahi, Brahma, Crussification, and Pew and so on. This is causing this disaster Covid-19.

\section{Covid-19 in 2020}

This Covid-19 started in 2019 in Wuhan province in China. Mitchell Tsai, Virus researcher at Harvard Medical School in 1980s said: "A key mistake was to assume that COVID would behave like seasonal flu.It does not behave like the flu at all. It spreads more slowly and has a longer incubation time. This makes it more difficult to detect, and to build immunity in the population." The history of human civilization, the world has showed many kinds of infectious diseases. These diseases will be contaminated millions and millions people and how many will be died which Allah knows well from this earth. The researchers don't want to go there. They want to describe in a short.

The scientist, Covid invents this symptom in 2019. This is renamed as Covid-19. In China, it is out-broken as a pandemic where it has spread out bats or seafood in Wuhan. There are four kinds of Coronavirus such as: alpha, beta, delta, and gamma coronaviruses. (WHO: March, 2020) Alpha CoVs and beta CoVs originated from bats and rodents while delta CoVs and gamma CoVs have their origins from avian species (Cascella $\mathrm{M}$ et al., 2020). The beta CoVs including SARSCoV-1 was isolated from bats in 1992 with civet cats being the intermediary host; MERS-CoV was isolated from dometry camels in 2003. (Anjorin, 2020)

It can be transmitted from human-tohuman by respiratory droplets from sneezing, coughing, and aerosols, with symptomatic people being the major source of transmission. It has a dynamic incubation period of about 7 to 14 days (Li $Q$, et al., 2020). This epidemic is created by man and woman. It will never drive out from the world. The more the whole world pray to forgive to Allah and trust to Him, the more the world people must not die only but also save economic, finance, wealth and lives. The 2020 year is the procession of death. Around the world millions and millions 
people lose all. It is called as a bioweapon which is created by humans.

To identify the features of the global disaster and to explain about the death of the global people which they lead their life style and to put up their studies how far the life style get their rights, prestige, dignity and honor. To introduce about the comparative all kinds of life style studies where they work from birth to death then the global people and their suffrage will study the world-people. Why the global people are to be died for an unknown crisis and get created frightened as a great terrible death? To introduce about the pandemic disaster comes to the human but why? This paper explores and examines about these causes. Time does not wait for none. As like sins don't forgive anyone in the world, the world-people get lost their lives. Here is to show how the global people lead their life.

Islamic religious philosophy is eternal truth where there is no wrong but always it tells the eternal truth. Here will be examined to the data of the religious philosophy, psychological philosophy and general philosophy where the global people find out a latest peace and condolence and nobody can deny it.

How do the world people lead their all styles of life? Why are they being died for unavoidable death? What causes to die the global people? What are the offences for this death and disaster? Are they culprit for this great disaster and destruction? Here the researcher tries to show the legal way of teaching and the dictation of the super power only Allah. Most of the global people have forgotten the valid ways of Allah. This causes creating disaster and destruction.This paper tries to identify about their social, economic, religious believing, marriage life and sex life, leading state power, invented matters and cultural values. Why the global climate is changing? Above mentioned matters are valid or invalid? This paper only tries to stop death and create a peaceful world. The contaminated and death toll are increasing away but all human must die. None can stop death. Only Allah can stop death. It will not be unavoidable death. This death will be eternal truth. Science and scientists can't stop death but they can be procrastinated death which is written by Allah.

The researchers try how to lead the pure religious life. In this case, they study that the holy and the glorious Quran how the global people treat to lead their life style in invention, belief, action, economic, state ruling, judging, eating, marriage, sex, ethic, morality, social coverage, cultural guesting, architectural beauty and family life. This holy and glorious Qur'an is a great freedom of Magna Charta for the global people. The authors try to discover the comparative study for the religious philosophy, psychology and philosophy.

Allah says his holy and glorious Qur'an: Pollution has appeared in the land and the sea by the hands of people for what they earned. He will make them taste some of what they have done, perhaps they will revert (Qur'an, 30:41).

And more Allah says: Say, "Roam the earth and see how the end was for those before. Most of them had set up partners" (Qur'an, 30:42). It shows that it is created by human which is clear and truth. It is also about destruction of the earth because of Polytheism, Ignorance, 
Nationalism, Oppression, Wars, Greed, and Waste (Yuksel, et al., 2007).

Here has been showed and introduced that this world is only for the male and the female who are mainly for their slavery articles. The male has invented religion but the female can't discover religion like them and all preachers and preceptors of the official religions are men. The authors try to refuse their demand and patriarchy. They think that there are female prophets in this world like male. They mention the female prophets. They are Deborah, Hannah, Asaph, Judith, Elezabeth, Eukhabez, Hazera, Huldah, Noadiah, Sarah, Abigail, Esther, Anna, Priscilla, Jounian, Andronicus and Mariam. This world how many times have been damaged for ages after ages, none can answer clearly.

All will be guessed as a hypothesis. What are the causes to destroy the world and civilization? In this article, he tries to show the divine rules, teachings and dictations which have come from almighty creator Allah. When the global people have forgotten the pure teaching, dictations and lessons from showing by Allah, the world has changed its own originality. Allah has sent his messengers to teach the learning of Allah to the global people. As they are misguided, the great disaster is snatched away their lives and civilization. The researcher explores the holy and glorious Qur'an which can set free from this type of great disaster. Human-made theories and inventions can never set free from this type of disaster. This Covid-19 is human-made. The punishment from Allah doesn't come from Allah. This is created by human.
The global people try invention how to kill the human within a second.

They invent bioweapons, hydrogen bomb, and many kinds' immunizations which can damage this world by throwing them in a second. They have many kinds of virology lab. Science can never bless for the world people. If the science with teaching by Allah becomes for human welfare, there will never come destructions and disaster. The teaching, medicine and dictation of the holy and glorious Qur'an can give only peace and peace and peace. The researcher tries to explore this Covid-19 by accepting the point of view of the holy and the glorious Qur'an because the holy and the glorious Qur'an is the greatest science in the universe which is the speech of almighty Allah.

\section{METHODOLOGY}

In this paper primary sources are used as the holy and the glorious Qur'an. These are various theological books, research articles and some books are from English. The secondary sources are used in this paper. Most of them are Google scholar, Academia.edu, Researchgate, Internet Browsing and qualitative based items. In this paper's all sources which are used here that are researcher's own private library and all collected sources from outline based article and book. Here will be followed APA style. Most sources are only primary and secondary. It will help to introduce the novel path which has been occurred for ages after ages.

In these ways, the global people do sins. The global people have to train death as a great curse. There science never does anything. It becomes worthless. It is the power of Allah. By the 
way of religious theme will be followed what has been said and taught by the almighty creator Allah. There is no Allah but Allah and Mohammad (PBUH) is His greatest messenger of all messengers. It varies to international research rules and regulations which may cover this hypothesis paper. Here tries to give up plagiarism. The researchers think that this process leads into a qualitative manner and etiquette.

\section{DISCUSSION}

This paper tries to identify why the global people affect to the great disaster per 100 years. The researcher has divided into two sections about this great disaster if it is also created by human. The global people have changed their main life style and social matters. To lead life, all components are interrelated to the sections such as inventions, researching, making policy, administration, beliefs, actions, economics, and power point policy, entertaining policy and eating policy. Above mentioned these are in two points of views. These are: (a) Causes and (b) Results.

\section{Global Climate Change}

Every day, the global people cut down trees at a random. For this quantity, the global people don't plant trees. They create at a deforestation atmosphere. Oxygen emitting is less than before emitting. They make up new building with cutting down mountain. The world is demounting. Here creates greenhouse effect, In that cases the global warming is growing up at a tremendous. Carbon dioxide is increasing at a high rate. Allah has created to protect the balance world by mountain. The global people have created to protect to the world. Allah says in His the holy and glorious Qur'an: The mount of ages (Qur'an, 95: 2). Allah has euthanized about mountain because it saves and protects the world. Allah says more in His holy and the glorious Qur'an: Thamud who carved the rocks in the valley (Qur'an, 89:9).

It is the symbol of the destruction from the world. Allah says in His the Holy and the Glorious Qur'an: To the mountains, how was it set? (Qur'an, 88: 19). The scientific inventions which are related into urbanization and transportation where there are being used pitch and alter. These emit smoke. It goes to mix with air and Oxygen. So it has exemplified to this connection. In the hydro-fluorocarbon (HFC) family that are used extensively in the air-conditioning and refrigeration industry. (Mukherjee: 2015) Besides these connections are to mountain and seas or rivers.

Allah says His holy and glorious Qur'an: The Mountains as pegs? (Qur'an, 78: 7) To bring out with it, seeds and plants, Gardens of thick growth? (Qur'an, 78: 16) The mountains He fixed firmly (Qur'an, 84: 32). When the seas are made to boil? (Qur'an, 81:6) When the seas burst? (Qur'an, 82: 3). Thamud who carved the rocks in the valley? (Qur'an, 89:9) The global people deny them and they perform anything what they will. They are unacknowledged with them. Almighty Allah says: We have poured the water abundantly. Then we cracked the land with cracks [Qur'an, 80:25-26].

The global people are guilty for the change of the global climate. In that case, there are many kinds of disasters such Covid-19. In the past civilizations, there 
have been occurred this type of pandemics such as plague, smallpox, cancer, diarrhea and today's Covid-19.

\section{Scientific Inventions}

The global people are main culprit for destroying the civilizations after civilizations. They are cutting down trees. They are cutting down mountain. They are researching how to kill people in a second. They are mixing with chemical, physics and chemistry and biological therapy in water, in earth and in air. The communication of the earth is increasing as supersonic type. There is a great funny matter that the source of scientific inventions is always changeable. The holy and the glorious Qur'anic sources are never changeable but its explanation is changed. The holy and glorious Qur'an accepts the various types of global people. Their language and culture are differentiated from Arabic language or Islamic civilization. The scientists have been tried to invent a new path where the global people can be benefitted to lead their life sphere. They try to mix with biological theme, material things and chemical things which produce a new sphere walk of life. This leads happy life. But most of the place, the global people affect a poisonous radiation which is a must harmful for mankind and womankind. There are many scientists have born in the earth. They can never stop death.

The prophets of Allah, who have said that from getting almighty Allah, then there have been, occurred that. None can save these epidemic events in the civilizations after civilizations.The mills, factories, research laboratory and mechanical field invent a new well fare invention. These are a great valuable for human civilization. After all, the global people suffer most where there create a new atmosphere which causes to death for the global people. To see, scientific invention is a great bless but other side it is a great curse. The super power countries of the world try to invent weapons which can fire this world in 250 times. This nuclear weapons, hydrogen bombs, oxygen bombs and biological bombs which are fully curse. In that case, their main motto is to kill the global people. If these inventions money would be used for world welfare, this world would have never faced to destruction. That means that all inventions have to ban. No, it would be invented for the global people's development. Every super power countries have virological laboratories where the scientists try to invent new theory how to kill the global people within a second without any war. The holy and the glorious Qur'an have impressed the global people. Among them who are the best who think and research about the land and sky.

\section{Religion and Belief}

About 11 million global people declare that there is no Creator or God or Allah. The persons, who believe creator or God, are called theist. They are differentiated in many sections. Some believe ONE-GOD or Allah. Some trust God is he and she. They worship to Gods and Goddesses. They worship to the Sun, the Moon, to the Trees, to the Stone, to the Stars, to the Jinn, to the Angels, to the Fire, to the Made-idolatry and to the Animals. They worship to the Person, to the Parson, to the Pope, to the Clergy, to the Guru, to the Khajababa, to the Chisty, 
to the Dihibaba, to the Haque Bhandary, to the Mazz Bhandary, to the Peer, to the Baba, to the Saai, to the Murshid Kibla, to the Father, to the mother, to the Bhagaban, to the Brahma, to the Visnu, to the Shiva, to the Maa Kali, to the Maa Durga, to the Bonbibi, to the Krishnan, to the son and so on.They worship to idolatry.

They are making state idolatry as the state sculptor.They have made a creator by stone or sand or iron or steel or soil like God. They are sharing to the GOD. To see, the time of Hazrat Nuh (A.S.) all people practice idolatry who are elite class people but they accept the religion of Hazrat Nuh (A.S.), they are very poor, honest, and wise. Few people accept his religion but most of the major people deny the religion of Hazrat Nuh (A.S.) One day they face to flood and they all had died and the people of Nuh would be saved by the dictation of Allah. Only there would be lived the people of Nuh (A.S.).

So, this type of idolatry-ism is full of all countries of the world. Every house is full of idolatry and idolatry. (Sayedee: 2009) Today, there is no house there has not been idolatry such as doll, idolatry, photo, image of animals, sculptor of painting and architecture. Even if, Muslims keep taking care of their houses such as painting of animals, photo of Peer, photo of parents, photo of brothers, photo of lovers, photo of wife, photo of kids, photo of players, photo of actor and actress, photo of poets, photo of scholars, photo of artists, photo of singers, photo of dancers and photo of political leaders and so on.

The researcher thinks that all countries of the world are floating on so called idolatry. Who is wicked than one who invents lies about God, or says: "It has been inspired to me," when no such thing inspired to him; or who says: "I will bring down the same as what God has sent down." If you could only see the wicked at the moments of death when the angels have their arms opened: "Bring yourselves out, today you will be given the disgraceful punishment for what you used to say about God without truth, and you used to be arrogant towards His signs" (Qur'an, 6:93).

In this way the world is full of wicked world. If they deny you, then say, "My works are for me, and your works are for you. You are innocent from what I do, and I am innocent from what you do" (Qur'an, 10: 41). The greatest messenger of Allah, Hazrat Mohammed assures them but they deny.

Now, they are full of the world countries. Say, "O people of the book, you are not upon anything until you uphold the Torah and the Injeel and what was sent down to you from your Lord." For many of them, what was sent down to you from your Lord will only increase them in transgression and rejection, So do not feel sorry for the ingrates. (Qur'an, 5:68) They are misguided. They do not accept Islam and the holy and the glorious Qur'an. For that, you shall preach and be upright, as you have been commanded, and do not follow their wishes.

Say, "I acknowledge all that God has sent down from book, and I was commanded to apply justice between you. God is our Lord and your Lord. We have our deeds and you have your deeds. There is no argument between us and you. God will gather us all together, and 
to Him is the ultimate destiny" (Qur'an, 42:15).

The researcher thinks that religion in the earth only for the global people is monotheism religion is the best which is Islam. So establish yourself to the system of monotheism. It is the nature that God has made the people on. There is no changing in God's creation. Such is the pure system, but most people do not know (Qur'an, 30: 30).

There is no alternative religion but Islam. Among the people are those who say, "We acknowledge God," but if he is harmed in the sake of God, he equates the persecution inflicted by the people with God's punishment! If a victory comes from your Lord, he says: "We were with you!" Is God not fully aware of what is inside the chests of the worlds? God is fully aware of those who acknowledged, and He is fully aware of the hypocrites (Qur'an, 29:10-11). A person who peacefully submits or surrenders herself or himself to God alone is a Muslim. In other words, it is a person who has accepted God as the only authority for eternal salvation and tries his or her best to follow and respect divine laws elucidated in scripture and nature. (Yuksel, et al., 2007)

\section{Social Unrest}

There are universal laws inherent in social structure and are learned through experience and through logical rules that dictate avoiding contradictions. The last six articles of the Ten Commandment can be learned from human experience. Societies that submit to the universal laws that justify communal life prosper socially and politically (Yuksel, et al., 2007).
O you prophet, if the acknowledging women come to make allegiance to you that they will not set up anything besides God, nor steal, nor commit adultery, nor kill their born children, nor fabricate any falsehood, nor disobey you in any matter which is righteous, then you shall accept their allegiance, and ask God to forgive them. God is Forgiver, Compassionate. $\mathrm{O}$ you, who acknowledge, do not ally a people with whom God is angry; for they have given up regarding the Hereafter, just like the ingrates have given up on the people who are already in the graves (Qur'an, 60:12-13).

The global society is restlessness. They denied our signs greatly. Everything we have counted in a record (Qur'an, 78: 28-29). The global society can't believe to other. Here thinks that total global society creates a social drama. Here all kinds of injustice and inhumanity have grasped all. Here is no truth. Truth is peeping few and pew. As for the one who transgressed. He was preoccupied with the worldly life. (Qur'an, 79: 37-38) In this way the global society is leading their life style where there is none welfare but naming global society. When the girl killed in infancy is asked, "For what crime was she killed?" (Qur'an, 81:8-9) For, he did not acknowledge nor support. But he denied and turned away (Qur'an, 75:31-32).

Surely, the human being is ungrateful to his Lord (Qur'an, 100:6). This global society doesn't respect the orphans. Here doesn't help the needy. Here doesn't provide to the inheritances who are the greatest getter. Here in only love for wealth. Here doesn't help needy when the time of famine. Here doesn't set free from the slavery. But Islam has banned 
the concubine age and slavery savage system. The One who taught by the pen. He taught the human being what he did not know (Qur'an, 96:4-5). Alas, the human being is bound to transgress. When he achieves, he no longer has need! (Qur'an, 96:6-7). Here is the present global society like the past society of Aad, Thamood, Iram, Pharao and Loot. Your Lord is ever watchful (Qur'an, 89:14).

Islam declares that there will not be killing kids and there will not be any slave. The freeing of slaves (Qur'an, 90:13) and Hazrat Ali Ibn Hussain (Ra:) calls his slave named Maatraaf and says: let you be free from the name of Allah. But this system has today in our global society. The global society has created millions diaspora who have not shelter, food, sleep, medicine, dress and so on. Those who have put the acknowledging men and women under ordeal, and then did not repent, they will have the retribution of hell, and they will have the retribution of burning (Qur'an, 85: 10).

The Age of Intellectual and Emotional Maturity are venturing. We instructed the human being to honor his parents. His mother bore him with hardship, gave birth to him in hardship, and his weaning lasts thirty months. Until he has attained his maturity, and reaches forty years, he says: "My Lord, direct me to appreciate the blessings you have bestowed upon me and upon my parents, and to do righteousness that pleases you. Let my progeny be righteous. I have repented to you; I am of those who have peacefully surrendered" (Qur'an, 46:15).

Today our society accepts to kill the womb kids in a validation. Do not kill your born children out of fear of poverty; we shall provide for you and them. The killing of them was a big mistake. (Qur'an, 17:41) In this way, the present all classes society lead their life style as a killer. Its symbol is seen by almighty creator Allah who has gifted the global people into hellfire and death suffering which the researcher is examined. Who are the sinners? The persons who tell lie, oath is broken and they are rebuked (Ibn Katheer, 2007).

\section{Marriage and Sex}

They are making a notorious condition in the global society. They are wedding to Polygamy, Polygyny, Polyandry, Lesbian, Gay and animal. They are only choosing wine and women. The global people practice above mentioned them. Even as the Muslim society perform polygamy and polygyny. They do not polygamy but practice polygyny. If you fear that you cannot be just to, fatherless orphans, to marry those whom you see fit from the women, two, and three, and four. But if you fear you will not be fair then only one, or whom you already have contract with so thatyou do not commit injustice and suffer hardship (Quran, 4:3).

You will not be able to be fair regarding the women even if you make every effort; so do not sway too greatly and leave her as one hanging in a void. If you reconcile and be aware, then God is Forgiving, Compassionate (Qur'an, 4:129) Recall God's blessings over you and His covenant that He has bound you with, for which you have said, "We hear and obey," and be aware of God; for God knows what is inside the chests (Qur'an, $5: 7)$. 
He is the One who sends the winds to be dispersed between His hands of mercy; so when it carries a heavy cloud, we drive it to a dead town, and we send down the water with it and we bring forth fruits of all kind. Thus we will bring out the dead, perhaps you may remember (Qur'an, 7:57). Islamic civilization has practiced polygyny. It is a great fun that they didn't practice polyandry. Polygyny of the male prophets of Allah was valid but not for their followers. Islam doesn't allow polyandry for womankind. The global religions allow it. Jew religion allows polyandry and Hindu religion doesn't deny it. In ancient past polyandry is valid. Now it practices in various countries in the world. The researchers think about Polyandry is the umbrella term for one woman maintaining sexual access to more than one man. This work is a comparison of forty-three societies as examples of the six types of polyandry practiced around the world. In some types, the sexual acts are part of a marriage contract involving three or more people. In some types, the marriage involves only two people, but the sexual access of the wife extends beyond the marriage (Benedict: 2001).

They are many kinds of polyandry. They are: associated polyandry, familial polyandry, fraternal polyandry, polykoity, secondary polyandry and walking marriage. It founds in the European colonial expansion, Tigara of Alaska, Marquesas Islanders, Cubeo of Colombia, Yanomami of Brazil, Hongkong Pahari, India, Cochin; the Nayars of Travancore and the Irava of British Malabar, Uttar Pradesh, Hymachayal Pradesh, Nepal and Tibetan polyandry and the Ache of
Paraguay. The male do sex with animal. Sexual contacts between the human male and animals of other species are not rare in the rural segments of our American population (Martino: 1974).

In a 1997 article, Piers Beirne, Professor of Criminology at the University of Southern Maine, points out that for genuine consent to sexual relations to be present both participants must be conscious, fully informed and positive in their desires. Bestiality is by nature sexual coercion because animals are incapable of genuinely saying 'yes' or 'no' to humans in forms we can readily understand. In human-animal relationships, the human has power and control over the animal, often in all aspects of the animal's care and wellbeing.

Thus, a sexual relationship between human and animal cannot be considered consensual. (Animal sexual: p. 1) Homo-sex is valid in the global society. It is seen the time of Hazrat Loot (A.S.). Allah has destroyed them from the earth that practiced homosexual, lesbian or gay sex. After millions year, it has been returned in our civilized world which is an order of constitution of the various countries of the world. The legalization of same-sex marriages in twelve countries around the world, together with the legal recognition of same-sex partnerships in other 21 countries has consider-ably changed the marriage institution worldwide. (Cortina: p. 1) The Muslim countries are not allowed homosexual but other world it is validated by rules and regulations. The little accident has been heard about lesbian and gay style sex in Muslim countries. In Muslim countries, same sex marriage is a blasphemy. 
Obviously truth, the few Muslim leaders, Visors, Uzirs, Amirs, Caliphs, followers of Mohammad (PBUH) and the world Muslim practiced polygyny, touring marriage and mutah (treaty marriage) marriage. And now it is practice by Muslim. It is surely negative practice according to the teaching of the holy and the glorious Qur'an.

\section{Economical Unrest}

The global societies and all countries of the world are creating usury based economic. Without usury, the world economic can't advance their economic. They can't lead their administration, state power, scientific invention, social strategy, local government, culture, education, agriculture, production, livestock, food, garments, food and religious department. The total world is in floating on usury. The persons who invent the best policy to create the way of microcredit usury development, they are awarded by Noble prize for the field of world peace. Islam fully denounces the usury management. The Islamic country doesn't come out from usury based economic. Usury based economic has been invalid forever for the Islamic civilization. Almighty Allah says: Those who consume usury do not rise except as the one who is being beaten by the devil out of direct touch. That is because they have said, "Trade is like usury."

Indeed God has made trade lawful, yet He has forbidden usury. Whoever has received understanding from His Lord and ceases, then he will be forgiven for what was before this and his case will be with God. But whoever returns, then they are the people of the fire, in it, they will abide eternally. God wipes out the usury and grants growth to the charities. God does not like any ingrate sinner (Qur'an, 2:275-276). Allah allows the business, trade and commerce. He has denounced the Riba or Usury. Everybody does not exploit the needy through Usury. O! You, who acknowledge, do not consume usury multiplying over, and be aware of God that you may succeed. Be aware of the fire that has been prepared for the ingrates (Qur'an, 3:130-131).

Usury can't provide peace. It is a fight against Allah. Because of the wickedness from those who are Jews, We made forbidden to them the good things that were lawful to them, and for their deterring many from the path of God.For practicing usury/interest when they were told not to, and for consuming people's money unjustly. We have prepared for the ingrates amongst them a painful retribution (Qur'an, 4:160-161). For this reason the global society has no love, passion, sympathy, take care, injustice and inhumanity. This causes this world is full of danger which is human-made that Allah has taken it as a punishment. Usury can exploit the world people and make the world's people as capitalism. It creates fraudulent in the world people. It can create a cruelty mind and soul. The global society is free from Zakat management. The persons who give Zakat, it is called as political Zakat.

All would give Zakat. Nobody would die for starving. Today, millions of tons food waste and they throw into water or river but not give to the hungry people. The Muslim finance is in Usury based because they have to usury percent to the International Monetary Fund, World Bank and Asian Development Bank and so on. There are many Islamic financial 
Banks who have to give usury to the IMF. They are not free from usury. In the name of Islam, they are called Islamic Banks. There is a great fundamental story where there are making Bank, who earn money by sexual work. They are practicing sexual commerce where they are earning money. They are making economical Bank by sexual working and sexual commerce. All societies, cultures, religions are in usury based economic dealing and Zakat free society.

\section{Killing Method}

The global state leaders are killing man and woman to gain state power at like a bird killing. Many countries have captured the peoples inherited land, wealth and they have driven from their motherland. Where they live from birth after birth, this place is their motherland. Bearing in motherland, they all are foreigners. They have to enter jail or to kill on the top of the gun's bullet. Today, the unislamic countries try to delete the name of Muslim from their lands. They are making torture cell, prison cell and raped cell. The Muslim societies are their main pain. Palestine, Kashmir. Rohyngya and all places of the world where the Muslim live, there are playing torture. All are known about Indian Muslim, Chinese Muslim, Myanmar Muslim, European Muslim, African Muslim, and American Muslim.

The world Muslim has no offences. The super power hit upon a plan how to create anti-islamic terrorism. They target them who have lost their lands, family, wife, kids, parents, brother, daughters and relatives. They try to return their lands and civilization. They are being used by the super power countries' policy. Want of wealth, money and food, they are victimized by them. This world is a crying of death which is in all around the world. They are becoming Diasporas or refugees. The global people are beating parents, killing parents and killing innocent kids. There are about eight crore people in the world. One of them is Muslims who are one hundred and sixty crore. About six hundred and forty crore are sharer to GOD. The twenty percent Muslim is truth and Haq. The other Muslims are in invalid ways that to be done.

\section{Weep of Womankind}

From the birth of the earth, the womankind has to tolerate the domination of the male. The male has snatched away their all kinds of rights, prestige, honor and dignity. The world official religions think that the womankind is the felinity, vanity and root of all kinds of sins. Islam has given their retuned all rights, prestige, honor and dignity. The womankind had to weep, weep and weep for centuries after centuries and civilizations after civilizations. Islam has returned their setting free from the chain of legs which is tyranny by the male domination. The male plays and leads polygyny. It is no validated by the holy and the glorious Qur'an.

The womankind has to weep in the house of heart. Almighty creator Allah declares: God cites as examples of those who have rejected, the wife of Noah and the wife of Hazrat Loot (A:S.). They were married to two of our righteous servants, but they betrayed them and, consequently they could not help them at all against God. It was said, "Enter the 
fire, both of you, with those who will enter it." God cites as an example of those what acknowledged, the wife of Pharaoh. She said, "My Lord, build a home for me near You in Paradise, and save me from Pharaoh and his works; and save me from the transgressing people." Also Mary, the daughter of Imran who is maintained her chastity. So we blew into her from Our Spirit, and she acknowledged the words of her Lord and His books; and she was of those who were obedient (Qur'an, 66:10-12).

\section{RESULTS}

This paper tries to explore the procession of death in 2020. Covid-19 is human-made? It is obviously truth that this great epidemic is created for many days' suffering, suffrage, killing, crying, forgetting almighty creator Allah, sharing to Allah and making Multi-gods and multi-goddesses. The researchers try to the method of psychological, historical, philosophical and religious values.

The global people create great epidemic which is taken by Allah as punishment. For creating Covid-19 is main culprit the global people. There are around eight hundred people in the world. About one hundred and six crore people are atheist. One hundred and fifty crore people are Muslim. This Muslims are differentiated in various sections. Some are Monotheist. Some are Peerism, Some are in folk-religious cults. The five hundred crore people trust in Multi-gods and Multi-goddesses. All are engaged into Shirk, Kufr, Moonafikism, Mooshrikiatism, Gibotism, Reeyaism, Bohtanism, Shekayetism, Oathebreakerism, Kheyanotism and eating Haram food. This world is full of unlawful sexual intercourse or fornication, adultery, cause an unlawful abortion, falsehood, to give to act of weighing, adulteration in food, obstinate to parents, not to help to the orphanage, defrauded to the just needy, act of robbery, act of stealing, act of snatching away goods, bribe, malpractice, abominable practice, injustice, inhumanity and all kinds of drugs.

The womankind who goes to work in the Middle East, the Middle East people seems that they are female slave. They can do sex as a valid. In this way, Islamic civilization has practiced anarchism. The present world has got new prophets such as Baha'i and Kadyani. Both of two are imposters. Allah has seen them ages after ages. The global people always think how to gain anything by fraudulent and killing. Allah gives time in a fixed date. It is known by Allah. None can know without Almighty Allah. They worship to the Sun, to the Moon, to the Fire, to the Iron, to the Air, to the water, to the Star, to the Angels, to the Jinn, to the Storm, to the Son of Allah, to the wife of Allah, to the friend of Allah, to the Messenger of Allah, to the Animal of Allah, to the Sand, to the Stone, to the Trees and to the Idolatry of Man and Woman of Allah. Without Islam, everyhuman of Hinduism, Christology, Buddhism, Sikhism and Judaism is God, Gods or Goddess or Goddesses For this reason, here is come down Covid-19 a great epidemic on the earth as a great punishment from the almighty creator of Allah. Allah declares his holy and glorious Qur'an: Corruption has flourished on land and sea as a result of people's actions and He will make them taste the consequences of some of their own actions so that they may turn back or 
Pollution has appeared in the land and the sea by the hands of people for what they earned. He will make them taste some of what they have done, perhaps they will revert. (Qur'an, 30:41)There are causing this Covid-19 great epidemic.

It will never vanish from our world. It will be kept in this world. The world famous historic argues that each dynasty or civilization has within itself the seeds of its own downfall. He explains that ruling houses tend to emerge on the peripheries of great empires and use the much stronger 'asabiyya present in those areas to their advantage, in order to bring about a change in leadership. This implies that the new rulers are at first considered "barbarians" by comparison to the old ones. As they establish themselves at the center of their empire, they become increasingly lax, less coordinated, disciplined and watchful, and more concerned with maintaining their new power and lifestyle. The 'asabiyya, dissolves into factionalism and individualism, diminishing their capacity as a political unit. Thus, conditions are created wherein a new dynasty can emerge at the periphery of their control, grow strong, and effect a change in leadership, beginning the cycle anew (Khaldun, 271-274).

$\mathrm{He}$ also further states in the Muqaddimah that "dynasties have a natural life span like individuals" and that no dynasty generally lasts beyond three generations of about 40 years each (Khaldun, 311-315). When the world is full of all kinds of sins, then here comes down a punishment which is mankindmade and womankind-made. The civilized world is today savagery in the worst type. The great philosopher,
Hodgson, Ralph says: Time, You Old Gipsy Man, Will you not stay? Put up Your Caravan, Just for one day? (Hodgson: 1917)

\section{CONCLUSION}

Above mentioned all must be banned. The global people should acknowledge Allah. We all should trust that "La-ilahaIllallah (Qur'an, 47: 19) or Akom Obo Ditiom Osy Nasti or There is no GOD but GOD. Allah has sent His messengers to get free the global people from ages to ages. His speech is clear. Let's all acknowledge Allah and obey, play his lessons to lead a happiness and peaceful world. Say [Prophet], 'If the whole ocean (a) were ink for writing the words of my Lord, it would run dry before those words were exhausted'even if we were to add another ocean to it. Say, 'I am only a human being, like you, to whom it has been revealed that your God is One. Anyone who fears (b) to meet his Lord should do good deeds and give no one a share in the worship due to his Lord. (Qur'an, 18:10- '10) This Covid19 has grasped away the humanlives anddestroyed away the wealth and finance power.

The mankind and womankind is shelter less to the almighty creator Allah. Above mentioned causes covid-19 is a great pandemic. The Human civilization never returns their losing wealth, finance and life. The human civilization should pray to GOD that all have to tell him that $\mathrm{O}$ ! My Lord, forgive them and all have driven out from our houses and state which God or Gods or Goddess or Goddesses have made by them or this world. Allah has given his introduction in the holy and the glorious: In the name of 
God, the Gracious, and the Compassionate. Say, "He is God, the One," "God, the Absolute/First-cause," "Never did $\mathrm{He}$ beget, nor was $\mathrm{He}$ begotten," "None is equal to Him." (Quran, 90: 1-4) Allah will be forgiven because Allah is the greatest merciful and the greatest justice. All should think world socio-eco-religio-politicological philosophy and comparative religion.

So, Covid-19 and so on is humanmade. It has become a punishment from Allah which is invented by human-made. When all men and women would follow GOD or Allah, the world could have been peace. There will never keep any destruction. This paper will show a novel path to invent anything who wants to study and read and criticize. The future generation has a great teaching from this research paper. Here is examined to the light of the holy and the glorious Qur'an.

This Qur'an is the greatest science and the greatest medicine who study the holy and the glorious Qur'an, they never misguide from the truth path of almighty creator of Allah. All have to acknowledge the teaching of Allah and should follow in all sphere of life.

\section{ACKNOWLEDGMENTS}

All praise to the Supreme creator, Allah who has created me as a male. This is caused that I try to invent the novel path for the field of research museum. Secondly I am indebted to my pious mother Mouree Begum who is to foster in keeping to her womb and she has taught me to discover the new and new source which may create a peaceful world. The pious father late $\mathrm{Md}$. Noab Ali who had also fostered me as possible as, he had supported and had been educated me. Thirdly all are to be stored if I don't acknowledge my sweet wife Shapla Khatun who has to tolerate my gap and my best life focused partner Shapla Khatun who always helps to hit upon a new plan for discovering and in particularly, has inspired to attend to the academic research studies. At last, I can't deny her vigorous inspiration that is my life partner Shapla Khatun who vigorously precedes my paper to open a new life to lead a scholarly life. My four children, Nazmus Sakib, Nazmul Arefin, Kitty Gemini and Kitty Joomaina who all are to feel gap from me when I try to write anything. Fourthly, in this way, there are scholarly scholar who guides me how to draft a research paper and they are Prof. emeritus, Dr. AKM Yaqub Ali, Prof. Dr. Ruhul KM Saleh, Prof. Dr. A.H.M. Akhtarul Islam, Prof. Dr. Mahfuzur Rahaman Akhanda, Principal Dr. Md. Mahbubur Rahman and Prof. Dr. Shahnaj Husne Jahan. 


\section{REFERENCES}

WHO. Coronavirus.[Online]. Available from:https://www.who.int/healthtopics/ coronavirus.[Cited on 14 March 2020].

Cascella M, Rajnik M, et al. .Features, evaluation and treatment coronavirus (COVID-19)" Treasure Island (FL): State Pearls Publishing; (2020).

Anjorin, Abdul Azeez A., "The coronavirus disease 2019 (COVID19) pandemic: A review andan update on cases in Africa", Asian Pacific Journal of Tropical

Medicine,doi:4.4103/19957645.281612, (2020), 13, p.1

Li Q, Guan X, et al. Early transmission dynamics in Wuhan,China, of novel coronavirus-infected pneumonia. NEngl J Med (2020).

doi:10.1056/NEJMoa2001316.

The Holy and the Glorious Qur'an

Yuksel, Edip, et al., (Trans. and Anno.), “Qur'an:A

ReformistTranslation",

(USA:BrainbowPress,Hundred

Fourteen Books

, (2007), p.267

Mukherjee, Manju Mohan, "Global Warming and Climate Change in India: A

Social Work Perspective", Whanake: the Pacific Journal of Community

Development, 3(1), n-n., 2015, p. 30

Sayedee, Maulana Delwar Hossain, "Bishoy BhittiqueTafsirul Quran, Vol1",

(Dhaka:Global Publishing Network, $2^{\text {nd }}$ Edition, March, 2009), p.12

Yuksel, et al, (Op.Cit), p.397, Ibidem. P.395

Ibn Katheer, Hafez Imam Uddin, "Tafseer Ibn Katheer, Vol-18", (Dhaka: Tafseer
Publication Committee, September, 2007), p.88

Benedict, Laura A.," Polyandry around the World", University of Nevada, Las Vegas,

bened11@unlv.nevada.edu, (2001)

Martino, et al, "Sexual Contact with Animals", Sex and the Intelligent

Women (C) Springer Science + Business Media New York (1974), p. 178

Cortina, Clara, Institut Barcelona d'Estudis Internacionals (IBEI) Spanish National

Research Council (CSIC), Laplante, Benoît, Institut national de la recherche

scientifique Université du Québec ,Fostik, Ana Institut national de la recherche scientifique Université du Québec, Castro Martín, Teresa Spanish

National Research Council (CSIC), "Same-sex marriages and partnerships in two pioneer countries, Canada and Spain", p.1

Khaldun, Ibn, F. Rosenthal (Trans.), "The Muqaddimah, Volume- III",

Hodgson, Ralph, "The Bull" "Time You Old Gipsy Man" (First Published, 1917). 